International Journal of

Supply Chain and Logistics

(IJSCL)

FACTORS AFFECTING THE PERFORMANCE OF COURIER SERVICE INDUSTRY: A SURVEY OF COURIER COMPANIES SS KENYA

Jacinta Wahu Nyaga

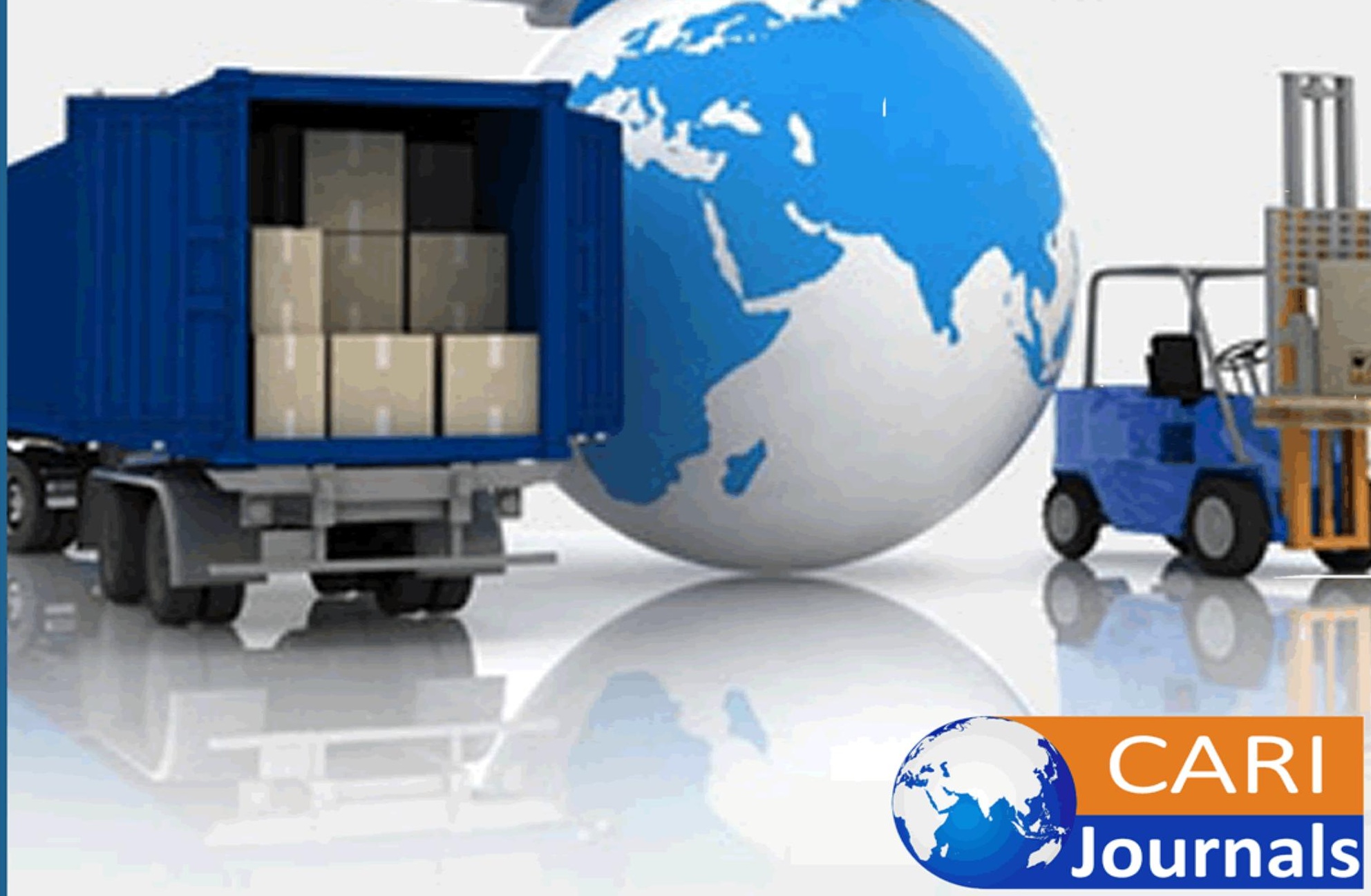




\title{
FACTORS AFFECTING THE PERFORMANCE OF COURIER SERVICE INDUSTRY: A SURVEY OF COURIER COMPANIES IN KENYA \\ 1* Jacinta Wahu Nyaga \\ ${ }^{1}$ Postgraduate student, Jomo Kenyatta University of Agriculture and Technology \\ *Corresponding Author's Email:jwnyaga@gmail.com
}

\begin{abstract}
Purpose: The study is an assessment of the factors affecting the performance of courier companies in Kenya.

Methodology: A descriptive survey study design was used. The population of this study was 134 courier firms. The sampling frame consisting of 134 firms was obtained from the CCK website. Stratified random sampling technique was used to select the sample. A sample of 68 firms was considered representative and they were selected by the use of the lottery method. The researcher opted for a questionnaire as a data collection tool. Data was analyzed by the use of descriptive statistics and specifically, means, frequencies and percentages. The analysis tools were simple tabulations and presentations using spreadsheets such as excel. The data was then presented using tables, charts and narratives.

Results: The study findings indicate that the companies have invested heavily into the training of their employees. Thus having in place a properly trained workforce can be said to be a factor that has contributed to the success being experienced in the courier service sector. From the study it emerged that there was high motivation among employees in courier firms as evidenced by their attitude towards work itself and promotion factors. However, they were not very happy with the pay factor. It is important to note that it would have been against logical expectation if the findings on the pay issue were different. The courier service firms come out as having in place reliable and very good customer service. The companies take into considerations suggestion made by the customer and prospective customers into the designing of products and services. ICT is another factor that attributes to the phenomenal growth of the courier service firms. Though the current state of infrastructure is bad, it seems to favor the growth of courier service firms. The courier firms have taken the challenge of poor infrastructure and turned it into an opportunity. In so doing, they have invested in motor bikes in order to beat the traffic jam challenge. This has enabled them to meet the demands of their clients increasing their popularity and hence more business.
\end{abstract}

Unique contribution to theory, practice and policy: The study recommended that future statistical research taking into account regression and correlation analysis can be conducted on the effects of the noted factors on the various growth indicators such as market share, revenues and profits. Such a study would verify or repute the findings of this study. Future study can also be conducted on an individual factor identified in the conceptual framework of this study.

Keywords: Performance, Courier Service Industry, Customer Service, Infrastructure, ICT 


\subsection{INTRODUCTION}

Courier Services are companies that transport and deliver documents, packages, and larger shipments of products, although traditionally they specialized in the rapid delivery of such items as legal documents that required signatures. They provide services to companies and individuals who need rapid service, accountability, and tracking that regular mail does not accommodate. Major courier services that performed these functions in the early 2000s included commercial delivery services, the U.S. Postal Service, and bicycle messenger services (Cohen, 2005). Courier services began during the late nineteenth and early twentieth centuries, with small companies in a handful of cities across the United States. When few homes had telephones, personal messages had to be carried by hand. Some early companies provided delivery of luggage and other packages. With the rise of large retail and department stores in the early twentieth century, package delivery services became even more popular. The scale of such services grew over the next several decades. Although fuel and rubber shortages during World War II caused a decline in the courier industry, the use of air freight by courier services after the war allowed for wider markets (Campbell, 2007).

Courier services became multifaceted and competitive after 1970 because of the increasingly farflung nature of business operations in the international economy, the popularity of mail-order retailing, and rising postal rates. Courier services overlapped other forms of transport, such as trucking, and the differences became less distinct. Commercial delivery services, once a supplement to the U.S. Postal Service, competed with the government operated mail system. The Postal Service responded with greater emphasis on its overnight Express Mail delivery and twoday Priority Mail service (Cohen, 2005). The growth and diversification of the delivery industry raised regulatory issues. Companies that delivered by plane or truck were often governed by separate laws regarding rates and other aspects of their operations. In the late 1980s the document delivery business faced new competition with the development of fax machines and Electronic Mail. The need for physical delivery of some items remained, however, and the delivery industry was bolstered by the continuing growth of the global marketplace, some delivery companies began to branch out and offer new services to their clients. These included "logistics," or support, services to help clients increase efficiency by electronically tracking materials used in manufacturing and assisting with processing sales orders and shipments (Kumar, 2006).

The Kenya Communications Act, 1998, mandates the Communications Commission of Kenya to license and regulate postal \& courier services in Kenya. This responsibility involves the issuance of licenses to all operators, regulation of tariffs for basic services, enforcement of regulations to ensure compliance with license conditions, and creation of order in the postal \& courier market. There are 134 postal and courier operators in Kenya, which include transporters and freighters that handle documents and parcels appropriately falling under the definitions given in the Kenya Communications Act 1998. Most of them have been licensed and a few have already been identified with a view to bringing them into CCK's regulatory framework.

According to the online standard newspaper edition published on 3oth April 2009, the liberalisation of postal and courier services has seen the sub-sector go through exponential growth in the recent past. Though not as glamorous as other sub-sectors in telecommunications, or even as popular among the masses as mobile telephony, revenues generated by courier services went up 86 per cent in the year 2008. According to Statistics from the Communication 
Commission of Kenya, total industry earnings stood at Sh1.99 billion as of December 2008, having almost doubled from Sh1.06 billion in 2007. Courier industry players say there is potential for further growth. The online standard newspaper article quoted Mr Vincent Kioko, general manager Overseas Courier Services Kenya (OCS) as saying that there is likelihood that more players, both local and international, would be making entry into the sub-sector.

According to the article, the global courier industry is looking up to emerging markets to reach the $\$ 225$ billion mark by 2012, that is, with collection and delivery of mail, letters, parcels and packages becoming an inevitable part of efficient modern-day organisation. The opportunities for courier services have been availed by growth in different sectors that has seen an increase in the number of companies setting up operations in Kenya. Another article by Mbogo and Lati (2009) states that, despite economic slowdown and technological advancement threats, postal and courier services are set to have a good year as more businesses outsource mail delivery to concentrate on core businesses.

The assessment by the Communication Commission of Kenya tallies with a new report by Price Waterhouse Coopers (PWC) which says global logistics industry, especially among the big players, grew as more consumers look for one-stop shops. Shift in consumer preferences is fuelling mergers and acquisitions, also buoyed by the fact that only the big corporations in the West and China have withered the shocks of global economic slowdown. "In the logistics and postal industry, bigger is often the better. Critical mass can create substantive economies of scale," notes the PWC report.

When the courier industry was liberalized in the late $90 \mathrm{~s}$, the number of courier services companies which have been licensed till early 2000 were 21 . Today, there are over 100 according to CCK statistics. The advent of Internet that facilitated efficient exchange of electronic documents and messages was seen as a threat to courier services. But the need for visible hard copy authentication on documents has made the sector stay afloat.

\subsection{Problem Statement}

Globalization and liberalization of the business environment in many sectors of the economy has meant more intense commercial competition both at domestic and global levels. Courier as a business sector has not been spared of this. Even in their home markets, companies are facing new competitors from around the world. As a result of increased global competition in courier business, the market player is faced with challenges of adjusting to this new business environment. There are issues within the organizations that need to be dealt with as they prepare to meet these challenges. At the same time, pressure to optimize the quality and costs of services is growing on companies.

Another challenge is the emerging high rate of adoption of information and communication technologies in carrying out transactions that were originally done by courier service providers. Globalization is creating new challenges to courier services in Kenya. More than 10 years ago, George Stalk, an American working at the Boston Consulting Group, announced the transition from cost- and price-based competition to "time-based competition (Mecham, 1992). In doing so, he summed up a development that had been brewing for some time: that a company's success was becoming more dependent on its ability to react immediately to customer requests. Furthermore, new technologies are being developed faster and faster in many areas. The result: 
The time frame for technologies or individual products to be commercially successful is becoming shorter.

Despite the above notable challenges, statistics from the communication commission of Kenya indicate that the courier industry has been on the growth path since year 2000. When the courier industry was liberalized in the late 90 s, the number of courier services companies which had been licensed till early 2000 were 21 . Today, there are over 100 according to CCK statistics. CCK statistics also point out that the revenue generated by the industry grew by 86 per cent in 2007; from Sh1.06 billion to Sh1.99 billion in 2008. In addition, the postal and courier industry has grown in value from KShs. 4.1 billion to KShs. 6 billion between 2001 and 2006 and as per CCK estimates, and this industry is expected to be worth KShs. 17 billion by 2013.

This scenario points out that there must be factors as well as intervening strategies that are impacting on the successful performance of the courier firms. Bearing this in mind, it was very important to study the factors affecting the performance of courier services in the country.

\subsection{Research Objectives}

i. Establish the relationship between employee training and performance of courier service industry in Kenya.

ii. Establish the relationship between employee motivation and performance of courier service industry in Kenya.

iii. Identify the effects of customer service on performance of courier service industry in Kenya.

iv. Establish the effects of the country's transport and communications infrastructure on performance of the courier service industry in Kenya.

v. Identify the effects of Information Communications Technology (ICT) on performance of the courier service industry in Kenya.

\subsection{LITERATURE REVIEW}

There is no general agreement on how firm size should be measured and therefore there is a wide variation on the growth variables used by researchers. A firm size may be measured according to its revenue or profits or by the amount of human and physical capital it employs (Barkham, 1996). This study considers sales and employment as growth indictors for the following reasons. First, the use of sales and employment measures are the most widely used in empirical growth research (Delmar, 1998). Second, those growth indicators are the only ones available in the present study for all the firms of interest. Sales are a relatively good indicator of size and therefore growth. Sales may be considered a precise indicator of how a firm is competing within a market, and indeed firms tend to use it as a measure of their own performance. An analysis of company growth should at least in part be based on changes in turnover.

However, sales are not the perfect indictor for growth for all purposes. Sales are sensitive to inflation and currency exchange rates, while employment is not. It is not always true that sales lead the growth process. For high technology startups and the startup of new activities in established firms, it is possible that assets and employment will grow before any sales occur. Obvious drawback of employment as a growth indicator are that this measure is affected by labor productivity increases, machine for man substitution, degree of integration and other make or buy decisions. A firm can grow considerably in output and assets without ant growth in 
employment especially technology based firms. Therefore, the combination of turnover and employment makes the measure more reliable (Barkham, 1996).

Turcotte et al. (2003) highlighted a strong link between business strategy and employee training. The authors found that firms emphasizing a human resources strategy or research and development strategy are much more likely to sponsor training than those with no strategy. Technology and innovation are also among the most cited determinants of employer support for training. Baldwin and Johnson (1995) found that companies that innovate, are more technologically advanced, emphasize quality management and have human resources strategies will more frequently support training initiatives. Baldwin and Peters (2001) similarly demonstrated that innovative firms are more likely to support training activities than noninnovative firms, but the former have a preference for on-the-job training. Innovative firms particularly favour acquiring experience, in the context of learning by doing, to enhance the ability of employees to innovate and solve problems.

A number of studies indicate that employee training has a positive impact on corporate performance. They generally test the hypothesis that, by improving the competency of employees, training also improves their productivity, which is reflected in an improvement in the firm's performance. Betcherman, McMullen and Davidman (1998) concluded that firms that have training programs tended to perform better in terms of productivity, revenues, profitability, viability and prospects. Saks et al. (2002) also found a positive relation between training and productivity, profit, revenue and client satisfaction, a relation that is more significant when the training is accompanied by incentives for the employees.

Our lack of adequate emphasis on motivation at work has, in all views, retarded the attempt to maximize performance. In their review of leadership studies, Hogan Curphy and Hogan (1994) found that only about 30 percent of line managers are able to adequately motivate the people who report to them. They imply that in most circumstances, motivation accounts for about half of all performance results. The late Tom Gilbert, one of the clearest thinkers in performance improvement, was fond of saying that when two people had equal abilities, the enthusiastic member of the pair would achieve about 70 percent more than the unenthusiastic person. Even more troubling is that evidence that a majority of the published studies of organizational development strategies that report measured increases in motivation are fatally flawed (Newman, Edwards \& Raju, 1989; Roberts \& Robertson, 1992). Strategies that may not work as powerfully or as consistently as claimed include popular employee empowerment strategies, contests, job redesign, leaderless teams and various performance recognition techniques

Customer service is an activity and program provided by the seller to the buyer to make the relationship a satisfying one. This is done through TQM, a management philosophy that seeks to integrate al organization functions to focus on meeting the customer needs and achieve the organization objectives. According to Kotler, (2002), customer service is it is an activity or benefit that one party offers which is essentially intangible and does not result in ownership of anything. Beach (1990) stated that customer service delivery begins with establishing clear concise, observable and realistic service standards that are precise in meaning, short and to the point, can be seen or measured, practical and attainable. This view was held by Campell (2000). A service is anything that is sold before production (Njane, 2002). This survey will give and insight into the type and quality of services that consumers want from an organization or service provider. These are the issues that consumers feel the firm should strengthen and are of 
importance if the firm is to become a key player in the market, some of these services are: Consumers want knowledgeable staff on matters of the business so staff should find out all they can; Customers want efficient and fast services; Customers want some regular feedback and contact from the company hence they should keep in touch and finally Customers would want a long-term relationship with the firm and hence shouldn't be taken lightly.

From a freight perspective, trading specialized production back and forth domestically and internationally, with as little cost as possible, is about more than simply lowering transportation costs. Manufacturers trying to reduce the cost of their "trade" interactions strive to lower their overall supply chain logistics costs relating to everything from the costs of distribution center warehouses, to the costs of carrying inventory, to the costs of transportation (ICF Consulting report,2001).

The goal is to lower the total cost of trade logistics. From a supply chain logistics standpoint, lower transportation costs and improved transportation reliability, that results from transportation investments, allow manufacturers to substitute transportation for more expensive distribution centers and the inventory they hold (Balaker,2006).We don't need inventory stacked up in multiple warehouses near every customer if we can rely on good transportation to quickly deliver what customers order in a fast and reliable way from a faraway production site. By making these substitutions of transportation for warehousing/inventory costs, manufacturers have found that they can often lower total logistics costs because the costs of warehousing and inventory go down by more than the extra aggregate transportation costs. This is true so long as we can get lots of good transportation (fast and reliable) at low unit transportation costs (Ascheur, 2005).

These principles have allowed U.S. companies to implement just-in-time (JIT) production and distribution techniques that lower the overall costs of trade and logistics domestically as well as internationally. At the same time these principles are allowing for transportation speed and reliability to increase responsiveness to changes in global demand. Because transportation costs less after proper transportation infrastructure investment companies can actually afford to buy more of it. So their transportation inputs and costs may actually go up because they can afford to use more of it, and they substitute that transportation for previous use of distribution centers and inventory. This allows them to lower their total costs of logistics (Robbins, 2006). But the key is reliable transportation systems and that takes investment in all modes of transportation, but especially highway transportation. Highways are key because trucking is the only mode that can offer the speed, reliability and low cost of unit transportation that is critical to the above supply chain logistics equation.

With the rapid change in the global state of ICT, most of the players in the communications industry inclusive of PCK and DHL have been forced to make operational adjustments. The effects have been adverse ranging from encouragement of new players into the communications business, rendering so many systems obsolete through product redesigning to personnel requirements. According to Han (2000), many people have embraced in communication the use of ICT to a very great extent in the recent past. The business volume in terms of the number of letter mail that PCK and other Courier service providers' holds per day has really gone down. This is because most people are using electronic mail (E-mail) to meet their communication needs. With improvement in technology, most transactions can now be carried out online in soft rather than hard copies (paper work) as traditionally were. Seemingly these have satisfied the consumers in terms of time. Courier firms were making a lot of money also through physical 
transfer of documents and reading materials e.g. books, magazines and journals. With improvement in technology, all the above mentioned materials/items can be converted into soft copies and be transmitted through electronic mails or be posted on the websites where the would be courier clients can get them online. Through the embracing of modern technology therefore, the sector has lost and chances are high that it will continue losing in its traditional business unless time in service delivery as a factor of quality is addressed.

\subsection{RESEARCH METHODOLOGY}

To achieve this overall objective, the researcher carried out a descriptive survey study of firms offering courier services. The population of this study was 134 courier firms. The sampling frame consisting of 134 firms was obtained from the CCK website and is given at the appendix named "population". To get the sample frame for this study, the researcher used a stratified random sampling technique. A sample of 68 firms was considered representative and they were selected by the use of the lottery method. The lottery method involves preparing 134 pieces of paper out of which 68 are picked at random. The researcher opted for a questionnaire as a data collection tool. Data was analyzed by the use of descriptive statistics and specifically, means, frequencies and percentages. The analysis tools were simple tabulations and presentations using spreadsheets such as excel. The data was then presented using tables, charts and narratives.

\subsection{RESULTS AND DISCUSSIONS}

\subsection{Response Rate}

Sixty eight (68) questionnaires were administered to the respondents. Sixty two (62) respondents filled the questionnaires and returned them; this represented a $91 \%$ of the sample. The findings are based on these responses.

\subsection{General Information}

The respondents were fairly distributed across both genders as shown in the figure below. 55\% percent were female while $45 \%$ were male. This implies that the findings of this study can be easily generalized across the two genders. On the issue the respondents' current position in the organization sampled there were varied responses on the managerial position held. Most notable (and the majority too-56\%) among the respondents were the operations managers who filled the questionnaire. This gives credence to findings of this study as the operation managers are well versed with growth of firms. The respondents were asked to state their highest level of education and the responses are illustrated in the figure below. Majority of the respondents were graduates (62\%), $24 \%$ were educated up to college level while a $14 \%$ had postgraduate education. None of the respondents had a doctorate. This means that the respondents clearly understood the dynamics of the firm and their responses were most likely relevant.

The respondents were asked for how long they have worked for their respective organizations. As shown in the figure below majority of the respondents had substantial experience in their respective firms. $60 \%$ of the respondents indicated that they had been in service in past 11-15 years while $25 \%$ had been in service for the last 5-10 years. Ten percent had been in service for less than five years while the rest $5 \%$ had been in service for over fifteen years. These findings suggest that the respondents had been in service for enough time to note the growth patterns and trends in the courier service sector. 


\subsection{Effect of Training on Performance}

In this section the respondents were questioned on issues which were a pointer on the influence of training on the growth and performance of their respective courier firms. The respondents were asked the frequency with which they underwent a list of given training courses since they were employed at their respective firms. The results are shown in the table below.

Table 1: Training Issues

\begin{tabular}{|c|c|c|c|c|c|c|}
\hline & Never & $\%$ Never & $\begin{array}{l}\text { Once or } \\
\text { twice }\end{array}$ & $\begin{array}{l}\% \text { Once } \\
\text { or twice }\end{array}$ & Severally & $\begin{array}{c}\% \\
\text { Severally }\end{array}$ \\
\hline Customer care & 8 & $13 \%$ & 6 & $10 \%$ & 48 & $77 \%$ \\
\hline Health and fire safety & 11 & $18 \%$ & 39 & $63 \%$ & 12 & $19 \%$ \\
\hline Conflict management & 5 & $8 \%$ & 18 & $29 \%$ & 39 & $63 \%$ \\
\hline Time management & 0 & $0 \%$ & 0 & $0 \%$ & 62 & $100 \%$ \\
\hline $\begin{array}{l}\text { Courses related to your } \\
\text { job }\end{array}$ & 23 & $37 \%$ & 34 & $55 \%$ & 5 & $8 \%$ \\
\hline $\begin{array}{l}\text { Work standards e.g. } \\
\text { receiving calls }\end{array}$ & 10 & $16 \%$ & 5 & $8 \%$ & 47 & $76 \%$ \\
\hline Presentation skills & 0 & $0 \%$ & 0 & $0 \%$ & 62 & $100 \%$ \\
\hline First aid skills & 21 & $34 \%$ & 23 & $37 \%$ & 18 & $29 \%$ \\
\hline
\end{tabular}

The respondents stressed that the courier firms have invested heavily into the training of their employees as they were the ambassadors of the firms and the way they interacted with the clients influenced heavily the chance of the client conducting business with the firm again and also referring other clients to the company. This was demonstrated by the majority $(77 \%, 63 \%, 100 \%$, $76 \%$, and $100 \%$ ) indicating that they had severally attended customer care, conflict management, time management, works standards and presentation skills training respectively. Very few respondents indicated that they had never attended the mentioned training. The training stressed the importance of customer care, presentation skills and timeliness. Other areas stressed were conflict management and work management. The training was conducted for both new and old employees in all ranks from senior management to the subordinate staff.

\subsection{Influence of Motivation on performance}

In this section the respondents were asked to state their opinion on various aspects of their jobs which are related to motivation in the workplace. A Likert scale was used to rank the opinions with ratings ranging from 1 for Strongly Disagree to 5 for Strongly Agree. The results are as reported in the table below. On the element of work itself the respondents were asked whether they had a chance to undertake varied tasks (job rotation) the results returned a mean score of 4.10 which means that most of the respondents moderately agreed with this assertion. This finding is also supported a majority of respondents (55\%) strongly agreement. Asked whether their jobs gave them a sense of accomplishment the results returned a mean score of 3.37 which means that they agreed with the statement. This finding is also supported a majority of respondents $(56 \%)$ moderate agreement. On the issue of empowerment the results posted a mean score of 4.21 implying that the respondents agreed that they were empowered to participate in 
decision making. This can be due to the fact that the respondents were drawn from management levels.

On the element of pay and compensation for efforts expended in the workplace the respondents were asked whether they felt that they were paid adequately. The results posted a mean score of 2.26 indicating that the respondent felt dissatisfied with the pay and reward given. The responses on whether they were paid commensurate with their work experience retuned a mean score of 2.13 was gotten. This implies displeasure on the compensation scheme. Asked whether the benefits given by the companies in the company were in line with those of other firms in the industry the respondents seemed to agree with a mean of 2.42. The finding implies that the respondents may be looking for greener pastures in other companies. This finding is also supported a majority of respondents $(73 \%, 37 \%$ and $45 \%)$ disagreeing with three respective statement.

\section{Table 2: Motivation}

Aspect Work itself

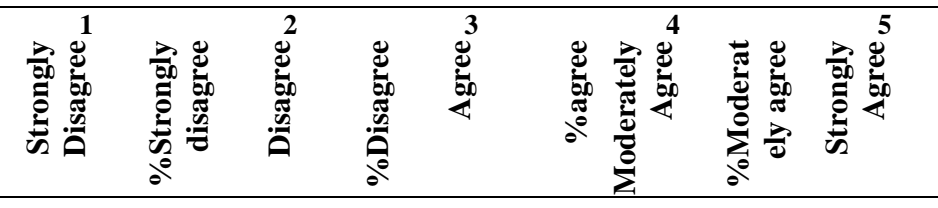

\begin{tabular}{|c|c|c|c|c|c|c|c|c|c|c|c|}
\hline $\begin{array}{l}\text { I have the chance to do different } \\
\text { things from time to time }\end{array}$ & 5 & $8 \%$ & 5 & $8 \%$ & 3 & $5 \%$ & 15 & $24 \%$ & 34 & $55 \%$ & 4.10 \\
\hline $\begin{array}{l}\text { The job gives me a sense of } \\
\text { accomplishment }\end{array}$ & 7 & $11 \%$ & 4 & $6 \%$ & 13 & $21 \%$ & 35 & $56 \%$ & 3 & $5 \%$ & 3.37 \\
\hline de & 3 & $5 \%$ & 3 & $5 \%$ & 6 & $10 \%$ & 16 & $26 \%$ & 34 & $55 \%$ & 4.21 \\
\hline Pay & & & & & & & & & & & \\
\hline $\begin{array}{l}\text { I am paid adequately for my } \\
\text { responsibilities and qualifications. }\end{array}$ & 2 & $3 \%$ & 45 & $73 \%$ & 13 & $21 \%$ & 1 & $2 \%$ & 1 & $2 \%$ & 2.26 \\
\hline have. & 17 & $27 \%$ & 23 & $37 \%$ & 20 & $32 \%$ & 1 & $2 \%$ & 1 & $2 \%$ & 2.13 \\
\hline $\begin{array}{l}\text { courier industry offer. } \\
\text { Promotion }\end{array}$ & 6 & $10 \%$ & 28 & $45 \%$ & 25 & $40 \%$ & 2 & $3 \%$ & 1 & $2 \%$ & 2.42 \\
\hline $\begin{array}{l}\text { There are fairly good chances for } \\
\text { advancement on this job }\end{array}$ & 6 & $10 \%$ & 7 & $11 \%$ & 4 & $6 \%$ & (4) & $68 \%$ & 3 & $5 \%$ & 347 \\
\hline $\begin{array}{l}\text { My organization has fair } \\
\text { promotion policies }\end{array}$ & 8 & $13 \%$ & 5 & $8 \%$ & 8 & $13 \%$ & 2 & $3 \%$ & 39 & $63 \%$ & 3.95 \\
\hline $\begin{array}{l}\text { The organization promotes people } \\
\text { on ability }\end{array}$ & 9 & $15 \%$ & 1 & $2 \%$ & 7 & $11 \%$ & 3 & $5 \%$ & 42 & $68 \%$ & 4.10 \\
\hline
\end{tabular}

The other element which the Likert scale sought to get opinions on motivation in the companies was the issue of promotion. On whether there were good chances of promotion in the company the results brought a mean of 3.47 implying existence of good chances. The respondents also strongly agreed with the statement that the companies promoted employees based on their abilities with this issue returning a mean of 4.1. The respondents also seemed to indicate that the firm has a fair promotion system in place with a mean of 3.95. While the results in the table paint a rather dull picture on the motivation of the respondents in their workplace, it is important to note that the respondents were happy with the work variable as well as the promotion variable. 
However, the respondents were unhappy with the pay related variables. This finding is also supported a majority of respondents $(68 \%, 63 \%$ and $68 \%)$ moderately and strongly agreeing with the statements.

\subsection{Influence of Customer Service on Performance}

In this section the questionnaire was designed with the aim of getting responses on customer care and how it relates to the growth of the firms in the courier service sector. The results are presented and discussed below.

Table 3: Customer Service Aspects

\begin{tabular}{|c|c|c|c|c|c|c|c|c|c|c|}
\hline Statement & 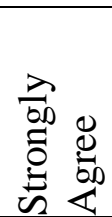 & 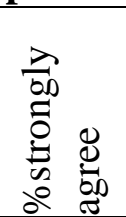 & 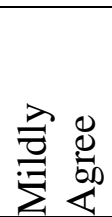 & 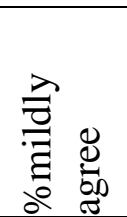 & 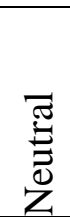 & 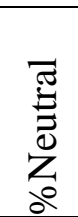 & 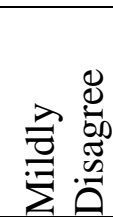 & 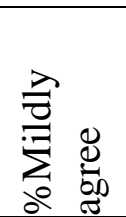 & 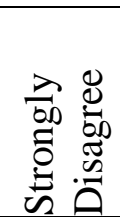 & 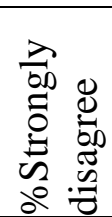 \\
\hline $\begin{array}{l}\text { My firm classifies } \\
\text { customers } \\
\text { various clienteles }\end{array}$ & 23 & $37 \%$ & 36 & $58 \%$ & 2 & $3 \%$ & 1 & $2 \%$ & 0 & $0 \%$ \\
\hline $\begin{array}{l}\text { My firm uses various } \\
\text { techniques to identify } \\
\text { customer needs and } \\
\text { predict their needs }\end{array}$ & 45 & $73 \%$ & 12 & $19 \%$ & 2 & $3 \%$ & 2 & $3 \%$ & 1 & $2 \%$ \\
\hline $\begin{array}{l}\text { My firm profiles the } \\
\text { customers and design } \\
\text { products to meet } \\
\text { their specific needs }\end{array}$ & 48 & $77 \%$ & 9 & $15 \%$ & 5 & $8 \%$ & 0 & $0 \%$ & 0 & $0 \%$ \\
\hline
\end{tabular}

Twenty three out of sixty two respondents, (37\%), strongly agreed to the fact that their companies classified their clients to various segments to enable serving them better. $58 \%$ of the respondents mildly agreed to this fact while $3 \%$ were neutral and only $2 \%$ mildly disagreed. Majority of the respondents, $73 \%$, also strongly agreed to the fact that the firm uses various techniques to identify customers' needs and this helps in designing relevant services to meet these needs. The majority of the respondents, 77\%, also indicated that their firms profiled clients/ customers and designed products to meet their specific demands. The results indicate that segmentation has been undertaken and used by the firms and thus improving customer service through customized services. The growth of the courier service firm can thus be attributed to the ability to segment the market and come up with customized products.

The majority of the respondents, $76 \%$ and $79 \%$ indicated that they collected and communicated customer information, discussed with their superior about the customer feedback once in a month. This implies that the courier firms took the customers feedback seriously. 
Table 4: Customer Information

\begin{tabular}{|c|c|c|c|c|c|c|c|c|}
\hline Statement & 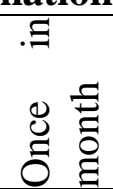 & 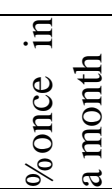 & 空 & 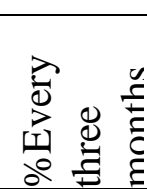 & 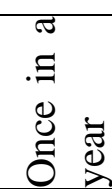 & 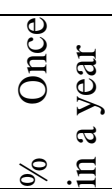 & 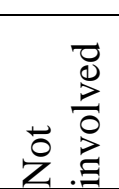 & 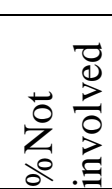 \\
\hline $\begin{array}{l}\text { How often do you } \\
\text { collect and communicate } \\
\text { customer information to } \\
\text { the company }\end{array}$ & 47 & $76 \%$ & 13 & $21 \%$ & 2 & $3 \%$ & 0 & $0 \%$ \\
\hline $\begin{array}{l}\text { How often do you } \\
\text { discuss with your } \\
\text { superior about customer } \\
\text { feedback }\end{array}$ & 49 & $79 \%$ & 9 & $15 \%$ & 4 & $6 \%$ & 0 & $0 \%$ \\
\hline
\end{tabular}

The respondents were asked whether there were company policies describing how to involve customers in designing service procedures. The results are as shown below in the figure.

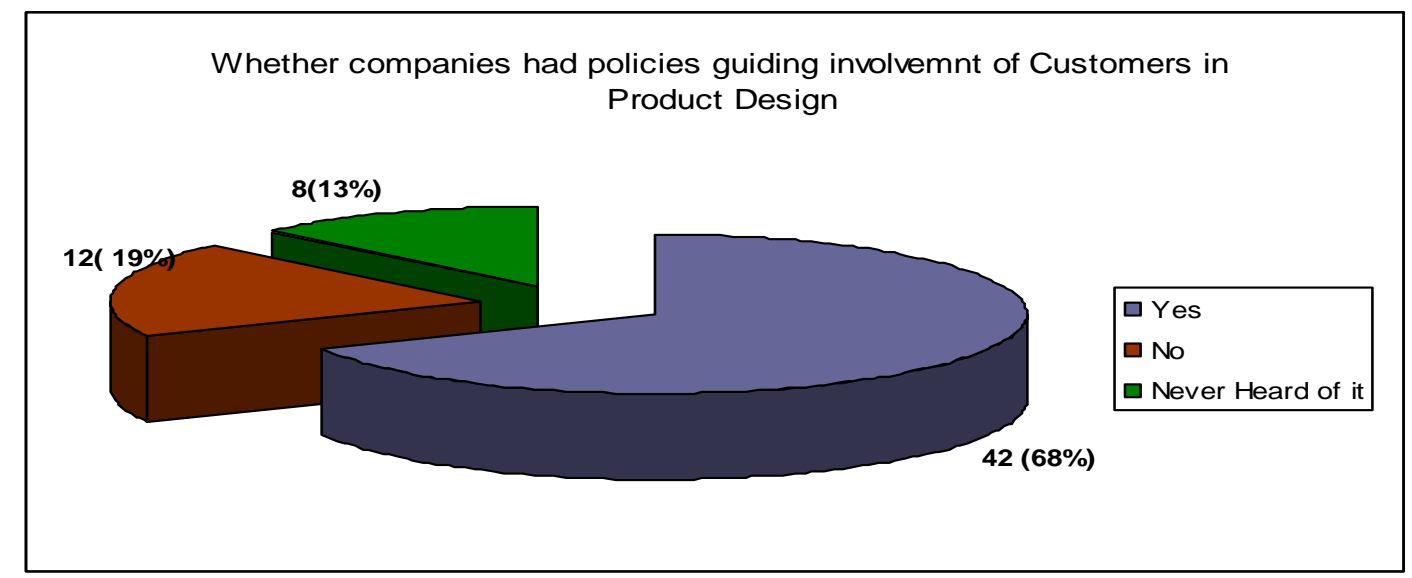

\section{Figure 1: Customer Involvement Policies}

$68 \%$ of the respondents indicated their companies had such policies in place. $19 \%$ indicated that their companies did not have such policies in place while the rest $13 \%$ indicated that they have never heard of such policies. Asked to explained the situation those who had indicated presence of policies indicated that the companies encouraged the recording of new service which the company did not have when requested by a customer. This was for example when a customer requested the company to take a parcel into an area it did not operate in. After explaining to such a client that the company did not ply such a route, the attendant is required to note down such a request. If the requests are many, the company starts operating in that area.

The respondents were asked whether there were customer service desk designated in every branch office. The respondents unanimously agreed that all the companies had in place customer service desks in all branches where requests of all kind concerning courier services were answered. In most of cases the desks double up as the collection points of the companies. 


\subsection{Effect of Transport Infrastructure on Performance}

In this section the study sought the views of the respondents linking infrastructure and firms growth. The respondents were divided on the effect of the road infrastructure on the effectiveness of their services.

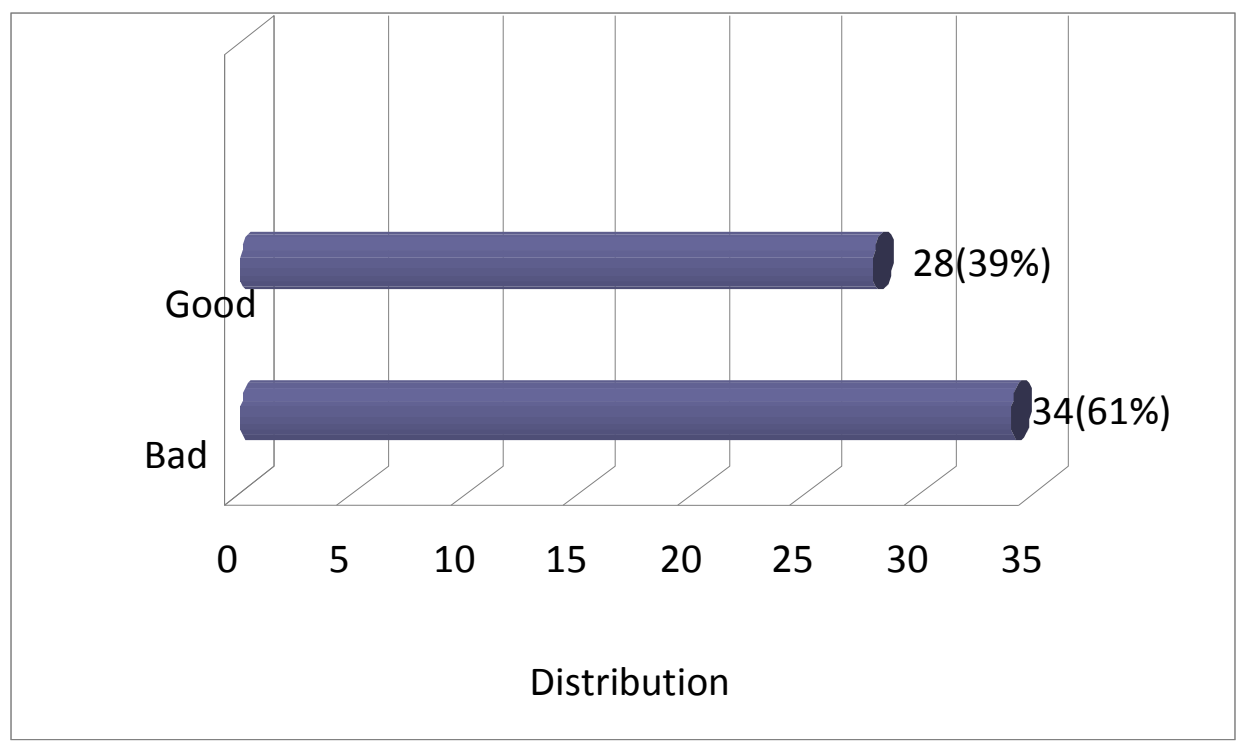

\section{Figure 2: Effect of Infrastructure}

$61 \%$ of the respondents indicated that the road infrastructure was bad. This was especially in the intra city bound dispatchments. On the other hand 39\% indicated that the road network was good. According to them, when it came to the long distance dispatchments, traffic jam and congestion was not a problem. All in all, the respondents argued that the main culprit was the incessant traffic jams plaguing the cities in Kenya. However, most of the players also took this as an opportunity investing on the use of motor bikes which easily maneuver through traffic jams and ensuring the customer needs are met.

\subsection{Impact of Information and Technology on Performance}

The majority of respondents, (90\%), agreed that information technology greatly influences the performance of courier service firms.

\section{Table 5: Impact of ICT}

\begin{tabular}{lcccc}
\hline & Yes & $\%$ Yes & No & $\%$ No \\
\hline Does ICT affect the performance of courier industry & 56 & $90 \%$ & 6 & $10 \%$ \\
\hline
\end{tabular}

The influence of ICT was said to be both negative and positive. On the positive side the respondents indicated that there were now able to track the parcels and consignments thereby increasing the security of clients' property which in turn builds a better corporate image for the firm which lead to a rise in customers who in turn lead to an increment on the revenues of the firms contributing to the growth. The embracing of technology has also enabled the companies to communicate with the customers using such tools as e-mail, thereby cutting on operating costs. The employees are also able to file real time reports to the head office using the same. The respondents also indicated that the internet provided a cheaper and effective advertising channel. 
On the negative side the respondents indicated that the courier service firms have been impacted negative as most of the small documents can be scanned and sent over the internet to the convenience of the recipient. Such documents include certificates, bills among others. This has eaten marginally to the market share of the courier which was accounted by sending such small documents.

\subsection{Other Factors Affecting Performance}

The respondents also suggested a few extra factors which were not captured in the conceptual framework. Such factors included the exceptional leadership and management of the courier services. The respondents indicated that the leadership helped in steering the companies to their unmatched growth. The respondents indicated that top executives with strong visions are great to have onboard. The management were delineated from the owners ensuring issues of corporate governance structure s were strong. The respondents also indicated that the ability to change and adjust to situations as well as coming up with innovative products as well as operating strategies have contributed to the success of the courier firms.

\subsection{DISCUSSION CONCLUSIONS AND RECOMMENDATIONS}

\subsection{Findings}

The respondents stressed that the courier firms have invested heavily into the training of their employees as they were the ambassadors of the firms. In addition, the respondents stressed that the way they interacted with the clients influenced heavily the chance of the client conducting business with the firm again and also referring other clients to the company. The training stressed the importance of customer care, presentation skills and timeliness. Other areas stressed were conflict management and work management. The training was conducted for both new and old employees in all ranks from senior management to the subordinate staff. Therefore, the training underwent by courier staff may explain the good performance of the courier industry.

The study findings suggest that majority of the respondents are motivated on the work related factors as well as on promotion factors. However, they were demotivated with the pay related variable. On the work related variable, all the three factors measured returned a mean score of more than 3, meaning that they were happy with their jobs. On the pay variable, the three factors measured returned a mean score of less than 2.5, meaning that the respondents disagreed /were unhappy. The three promotion factors returned a mean of over 3 indicating that the respondents agreed with the statements and were therefore happy with then promotion opportunities offered by courier firms. These findings indicate that the high level of motivation observed in courier firms may explain the observed good performance of courier firms.

On the issue of customer service the courier firms were found to have in place exemplary strategies in place. The results indicate that segmentation has been undertaken and used by the firms and thus improving customer service through customized services. The growth of the courier service firm can thus be attributed to the ability to segment the market and come up with customized products. Majority of the respondents indicated that their companies had in place customer service policies allowing the participation of customer input and information into the new product design and reevaluation of existing products. The respondents unanimously agreed that all the companies had in place customer service desks in all branches. The growth of the 
courier service firm can thus be attributed to the good customer service observed in the courier industry.

The majority of the respondents indicated that the road infrastructure was bad. This was especially in the intra city bound dispatchments. On the other hand, the minority indicated that the road network was good. According to them, when it came to the long distance dispatchments, traffic jam and congestion was not a problem. All in all, the respondents argued that the main culprit was the incessant traffic jams plaguing the cities in Kenya. However, most of the players also took this as an opportunity investing on the use of motor bikes which easily maneuver through traffic jams and ensuring the customer needs are met. The ability of courier firms to turn the transport infrastructure challenge into an opportunity may explain the good performance of courier industry.

The majority of respondents agreed that information technology greatly influences the performance of courier service firms. The influence of ICT was said to be both negative and positive. On the positive side the respondents indicated that there were now able to track the parcels and consignments. The embracing of technology has also enabled the companies to communicate with the customers using such tools as e-mail, thereby cutting on operating costs. The employees are also able to file real time reports to the head office using the same. The respondents also indicated that the internet provided a cheaper and effective advertising channel. On the negative side the respondents indicated that the courier service firms have been impacted negatively as most of the small documents can be scanned and sent over the internet to the convenience of the recipient. The findings imply that the positive effects of ICT on courier industry outweigh the negative effects. Hence, ICT adoption may explain the good performance of courier firms

The respondents also suggested a few extra factors which were not captured in the conceptual framework. For example, strong leadership, existence of corporate governance mechanisms and being continuously innovative helped firms to grow.

\subsection{Conclusions}

The study findings indicate that the companies have invested heavily into the training of their employees. Training programs undertaken by the firms ensure that the employees and the management are proficient in the assigned duties and exhibit the highest level of professionalism. Thus having in place a properly trained workforce can be said to be a factor that has contributed to the success being experienced in the courier service sector. The study findings suggest that majority of the respondents are motivated on the work related factors as well as on promotion factors. However, they were de-motivated with the pay related variable. Thus, the high level of motivation observed in courier firms may explain the observed good performance of courier firms.

On the issue of customer service the courier firms were found to have in place exemplary strategies in place. The growth of the courier service firm can thus be attributed to the good customer service observed in the courier industry. The majority of the respondents indicated that the road infrastructure was bad. This was especially in the intra city bound dispatchments. On the other hand, the minority indicated that the road network was good. However, most of the players also took the challenge as an opportunity investing on the use of motor bikes which easily maneuver through traffic jams and ensuring the customer needs are met. The ability of 
courier firms to turn the transport infrastructure challenge into an opportunity may explain the good performance of courier industry. The findings imply that the positive effects of ICT on courier industry outweigh the negative effects. Hence, ICT adoption may explain the good performance of courier firms

\subsection{Recommendations}

On the issue of training, the company has to include contemporary refresher courses for the employees and the management in emerging areas of customer care. As the courier firms deal in valuable consignments they should properly motivate their employees as the gains currently being made can be reversed if the employees' dissatisfaction is not addressed. This might lead the employees to resort into stealing the valuable consignment and reporting them as stolen or lost. The demotivated and demoralized employees can easily collude with criminals to the detriment of the company. Such acts will in turn tarnish a company's image leading to loss of business and even a firm collapsing.

The courier firms should adopt the practice of customer satisfaction surveys as a way of gauging the level of customer satisfaction. The courier industry should continue taking the current challenge as an opportunity. In so doing, they may invest in bicycles to maneuver the chronic city traffic jams. In addition, they should subcontract other firms for upcountry assignments. On the technological front the courier services need to watchful on the turn of events to ensure they are made obsolete by the technological advances. They have to come up with innovative products and see whether the use of technology can help them in expanding into other regional and global markets.

\subsection{Suggestions for Further Studies}

The study suggests that future empirical research can be conducted on the effects of the noted factors on the various growth indicators such as market share, revenues and profits. Such a study would verify or repute the findings of this study. Future study can also be conducted on an individual factor identified in the conceptual framework of this study. A deeper analysis of the effect of each one of these factors would clearly bring out the issues which seem to be somehow unclear in the study. For example a study can be on effect of Technology on the growth of courier service firms.

\section{REFERENCES}

Baldwin, J., \& Johnson, J. (1995). Human Capital Development and Innovation: The Case of Training in Small and Medium-Sized Firm. Statistics Canada, Ottawa, No. 7411F0019MPF No. 74, 44 p.

Becker, B. E., Huselid, M. A., \& Ulrich, D. (2001). The HR scorecard: Linking people, strategy and performance. Boston, MA: Harvard Business School Press

Becker, B., \& Gerhart, B. (1996). The impact of human resource management on organisational performance: Progress and prospects. Academy of Management Journal, 39:779-801. 
Campbell, James I. Jr, (2007). Evolution of the postal function and the need for a convention on international postal systems. Draft of paper presented at the Fifth Königswinter Seminar in Postal economics: Towards a New Regulatory Framework for Cross-Border Mail, Königswinter, Germany 5-7 November 2007

Chowhan, J. (2005). Who trains? High-tech industries or high-tech workplaces? Statistics Canada, Ottawa, No. 11-622-MIF No. 006, 69 p.

Clark, K.F. (2001). What businesses are doing to attract and retain employees-becoming an employer of choice, Employee benefits journal, March 2001.

Cohen, R. H., Chu, E. H., Ferguson, W. W., \& Xenakis, S. S. (2008). A cross sectional comparison and analysis of productivity for 21 National Postal Administrations" in Managing Change in the Postal and Delivery Industries, Ed. Michael A. Crew and Pul R. Kleindorfer, Dluwer Academic Publishers, January 2008.

Communications Workers' Union, (2005). Freedom to deliver: Postal Services Green Paper, London, February 2005.

Delaney, Robert, Council of Supply Chain Management Professionals, Annual Logistics Costs in the U.S. Economy, 2004, p. 6.

Firth L, David J., Kathleen, A., \& Moore, C. L. (2007). How can managers reduce employee intention to quit? Journal of management of Psychology, 19 (2):170-187.

Gaffin, A., (1994). DHL takes advantage of telephone server tool. Network World, 11(26), p. 39.

Han, K. S., \& Noh, M. H. (1999-2000) Critical failure factors that discourage the growth of electronic commerce, International Journal of Electronic Commerce, 4(2), 25-43.

Hanson, R. M. (2006), Employee organisation linkages: The psychology of commitment, absenteeism and turn over. United States University.

Intermodal Association of North America, (2006). DOT unveils congestion initiative. Intermodal Insights, July, 2006. 
International Labour Organization, (ILO) (2006). Structural and regulatory changes and globalization in postal and telecommunications services: The human resources dimension. International Labour Office, Geneva, 2006.

Kotler, P., Roberto, N., \& Lee, N. (2002). Social marketing, improving the quality of life. London.Sage.

Leung, L. C., \& Cheung, W. (2000). An integrated decision methodology for operating an airexpress courier distribution networks, Decision Science, Vol. 31 No.1 Winter 2000.

Locke, E.A. \& Latham, G.P. 1990. Work motivation: The high performance cycle. In Kleinbeck, U., Quast, H., Thierry, H. \& Hacker, H. (Eds.) Work motivation. Hillsdale: Lawrence Erlbaum

Price Waterhouse, A Strategic Review of Progressive Postal Administration: Competition, Commercialization and Deregulation, February 1996 Update, a study conducted for the United States Postal Service, February 1995 and Update February 2003.

Ranganathan, K. (2004). Redirecting the post: International postal sector reform. World Bank, Private Sector Development Department, Washington, D.C.

Saks, A., Taggar, S., \& Haccoun, R. (2002). Is training related to firm performance? Human resources management research quarterly, International Alliance for Human Resources Research, 6(3), 5.

Turcotte, J., Léonard, A., \& Montmarquette, C. (2003). New evidence on the determinants of training in Canadian business locations. Statistics Canada, Ottawa, No. 71-584-MPE No. $5,94 \mathrm{p}$.

Yin, R. (1994). Case study research: Design and methods. $\left(2^{\text {nd }}\right.$ ed.). Beverly Hills, CA: Sage Publishing. 